\title{
Disturbances of the cognitive functions of vehicle drivers in selected diseases
}

\section{Zaburzenia funkcji poznawczych osób kierujących pojazdami w wybranych jednostkach chorobowych}

\author{
Rafał Łoś $\hat{s}^{1}$ Ewa Latała-Łoś ${ }^{2}$ \\ ${ }^{1}$ Collegium Medicum, Jan Kochanowski University, Kielce, Poland \\ ${ }^{2}$ Regional Occupational Health Center, Kielce, Poland
}

Key words: automobile drivers' examination, cognitive functions, mental disorders, neuropsychological tests, road safety.

Słowa kluczowe: badania kierowców, funkcje poznawcze, zaburzenia psychiczne, testy neuropsychologiczne, bezpieczeństwo drogowe.

\begin{abstract}
Cognitive dysfunctions such as memory, attention, and orientation may occur in many disease entities, including those not included in the sphere of mental disorders. Their presence can significantly affect the ability to drive vehicles and road safety. The literature on the subject is dominated by studies assessing the functioning on the road of people driving vehicles with diagnosed cognitive disorders of various aetiologies. It is natural to divide them into disorders resulting from the pathology of the central nervous system and cognitive dysfunctions present in the course of typically somatic diseases. Assessment of identified abnormalities usually involves several stages, but the most documented method of evaluating disorders is neuropsychological examination.
\end{abstract}

\section{Streszczenie}

Zaburzenia funkcji poznawczych, takich jak pamięć, uwaga, orientacja, mogą występować w wielu jednostkach chorobowych, również niezaliczanych do sfery zaburzeń psychicznych. Ich obecność może istotnie rzutować na zdolność do prowadzenia pojazdów oraz bezpieczeństwo na drodze. W piśmiennictwie przeważają badania oceniające funkcjonowanie na drodze osób kierujących pojazdami, u których stwierdzono zaburzenia poznawcze o różnej etiologii. Naturalny jest podział na zaburzenia wynikające z patologii ośrodkowego układu nerwowego oraz dysfunkcje kognitywne obecne w przebiegu schorzeń typowo somatycznych. Ocena stwierdzanych nieprawidłowości jest zazwyczaj kilkuetapowa, ale najbardziej potwierdzonym w badaniach sposobem ewaluacji zaburzeń jest badanie neuropsychologiczne.

\section{Introduction}

Driving a vehicle requires the driver to have not only the necessary knowledge of road traffic law and appropriate skills, but also good physical and mental health. Meeting the minimum health criteria is necessary so that a person driving motor vehicles can do it in a safe way for him/herself and other road users. In Poland, the current health requirements for the health condition of applicants or drivers of vehicles have been defined in relevant legal acts systematically updated and adapted to the requirements in force in European Union countries. Taking into account the legal status in the field of medical examinations of candidates for drivers and drivers, the necessary knowledge necessary to properly conduct the examination should also be available to a doctor authorized to perform these examinations. Based on the medical history and physical examination, it is necessary to assess whether the examined person has any mental disorders that may constitute a contraindication to driving. One of the aspects of this assessment is the identification of cognitive disorders of various aetiologies. The causes of organic brain damage manifested by disorders of cognitive functions include the following: vascular brain damage, brain tumours, craniocerebral injuries, dementia syndromes, Parkinson's disease, and secondary dysfunctions caused by somatic diseases. In order to analyse the issue being the subject of the article, a literature review was carried out using scientifically recognized online medical databases: Pub Med, Google Scholar, and Polish Medical Bibliography. 
The following keywords were used for the search: driver research, cognitive functions, mental disorders, psychological tests, driving safety.

\section{Definition and types of research on cognitive functions}

Cognitive functions are those mental activities that help people to gain orientation in the environment, to obtain information about themselves and their body, to analyse situations, formulate conclusions, and make the right decisions and take appropriate actions. They include perceptual processes (impressions, perceptions), attention, learning, memory, thought, and language processes (speech and language) [1].

Methods for studying cognitive function include neurophysiological and neuropsychological studies. The first are objective methods, which include the following: visual or auditory evoked potentials, nerve conduction, brain mapping, functional magnetic resonance imaging, spectroscopy, and positron emission tomography. Neuropsychological methods allow for a more detailed functional assessment, they are useful in determining the type and degree of disorders. Detailed test methods are usually preceded by a screening test. The screening tests are, for example, the Mini Mental State Examination (MMSE), the Clock Drawing Test, and the Short Mental State Test [2].

\section{Cognitive disorders and the ability to drive vehicles in selected diseases of the central nervous system}

The literature review shows that the authors are very interested in mental disorders in which the impairment of cognitive functions is one of the symptoms of nervous system diseases.

The first (which seems to be understandable) and most common is dementia syndrome. Dementia is a symptom complex caused by a brain disease in which higher cortical functions such as memory, thinking, orientation, understanding, counting, learning, and language are impaired. Dementia is most often Alzheimer's disease, but also vascular dementia, Lewy body dementia, or frontotemporal dementia. They represent a significant risk factor in relation to driving a car. The necessity to develop a strategy for assessing the fitness to drive is therefore an unquestionable necessity. Three types of assessment are most often used as test elements: clinical history, neuropsychological tests, and driving simulators. It seems that the neuropsychological assessment may play the most important role, and it has not been demonstrated that the 3 types of assessment combined significantly exceed the value of the neuropsychological examination [3]. A diagnosis of dementia may suggest the ultimate need to give up driving, but patients differ significantly in terms of the course of the disease. An attempt to identify factors relevant to driving ability was undertaken in a 2018 study. Both baseline disease characteristics and changes in cognitive function over time were taken into account as indicators of the disease trajectory. The study involved 979 patients from 9 clinics in Australia diagnosed with dementia. Of the 247 patients who were still driving at the start of the study, 147 (59.5\%) had discontinued driving during the study. Variables predicting driving discontinuation included the following: older age, female gender, greater severity of dementia and early cognitive and executive impairment, and greater increase in dementia and cognitive and executive impairment over 3 and 6 months. The obtained data support the thesis that the changes that can be assessed during the examination of cognitive functions, to some extent, allow us to predict the future mental state and driving ability in the perspective of several years [4].

As the number of patients with Alzheimer's Disease (AD), the most common form of dementia, grows, and so does the number of patients driving a car, it becomes necessary to evaluate each patient for their ability to drive. The above-mentioned 3 predictors of driving ability were also used in a Dutch study involving $81 \mathrm{AD}$ patients and 45 healthy people. All of them participated in a clinical interview and were examined with a battery of neuropsychological tests and a simulator driving test. The driving ability criterion was determined in the road driving assessment by experts of the CBR testing organization in accordance with their official protocol. All 3 types of ratings were found to predict road performance. The neuropsychological assessment showed the highest value, followed by simulator driving, and clinical interview [5]. In addition to diseases manifested by the symptoms of dementia, a separate category is mild cognitive impairment (MCI), which comprises a set of clinical symptoms, mainly memory disorders, at risk of developing Alzheimer's disease. People with MCI may also require an assessment of driving ability, although few studies have addressed the problem of driving predictors among people with MCI. This topic was also taken up by Australian authors, who assessed the cognitive performance of $185 \mathrm{MCI}$ patients and their ability to drive vehicles at regular intervals over 3 years. Of the 144 people who drove at the start of the study, $50(27 \%)$ had stopped driving the car during the test. Older age, greater cognitive and functional impairment, and a greater decline in cognitive and functional functions after 6 months predicted discontinuation of driving. Twenty-nine (58\%) out of 50 people who stopped driving were diagnosed with dementia during the study; all but one stopped driving after being diagnosed with dementia. Thus, a significant percentage of people diagnosed with MCI stop driving within the next 3 years [6]. 
The databases contain quite a large number of works on driving by people with severe acquired brain damage. They focus on finding tools, in particular neuropsychological tests, with predictive value for a safe return to driving. The resumption of driving is perceived by patients as the main need because it is closely related to personal autonomy, work, and social activity. In a 2018 study, a battery of neuropsychological tests assessed 127 unstable patients with a history of brain injury, well integrated at the family and social level, at least 1 year after the completion of intensive rehabilitation. The studies assessed the efficiency of cognitive functions, then analysed them in relation to the requirements for driving tests. The test results were found to be significantly correlated with the driving license test result, even though there is insufficient evidence of the relative value of non-road compared to direct on-road tests. The authors proposed a "small battery of neuropsychological tests" in order to screen patients for possible dangers on the road [7]

A similar conclusion was formulated in the 2016 study. The relationship between the results of cognitive tests and the assessment of driving on the road in a sample of people with traumatic brain injury was assessed. Cognitive tests were predictors of road driving performance, but researchers concluded that the mere presence of brain damage is a stronger indicator, although further research on this issue was also suggested [8]. Similar results were obtained in 2011; moreover, the relationship between the ability to drive vehicles and the awareness of existing cognitive deficits was found [9]. The problem of acquired brain injury is also related to the problem of assessing the ability to drive vehicles of people after stroke. Two studies that can be found on this issue again focus on the issue of neuropsychological tests relevant to the study of identified cognitive deficits. The first of them, based on the analysis of databases since 1966, indicates the following tests: the Trail Making Test and the Rey-Osterreith Complex Figure Design. Both of these tests assess multiple cognitive domains related to driving and appear to have the best reproducibility in predicting driving ability in stroke patients [10]. The second study describes a battery of tests called the Nordic Stroke Driver Screening Assessment (NorSDSA), which was intended to predict the result of a road test among people who had had a stroke. However, the final results did not confirm the usefulness of the test in this respect [11].

Several studies in databases deal with the problem of cognitive impairment and, consequently, the ability to drive vehicles among people suffering from multiple sclerosis. Cognitive impairment is common in this patient population and, together with reduced mobility, should be carefully assessed. One study recruited people aged 18-59 years with multiple sclerosis. Cognitive performance was assessed using the minimal cognitive assessment battery. A formal road driving assessment was also carried out. Statistical analysis examined the relationship between driving ability (positive/negative) and the results of the neuropsychological test (normal/impaired). Of the 36 respondents, $8(22.2 \%)$ were unable to drive. This result suggests that in patients with multiple sclerosis, the finding of reduced cognitive performance should prompt clinicians to conduct an in-depth neuropsychological assessment [12]. Other studies indicate the need for an initial assessment of the cognitive functions of people suffering from multiple sclerosis as a basis for further, in-depth diagnostics [13]. All authors also agree with the statement that the results of cognitive tests in the study of people suffering from multiple sclerosis are a predictor of driving safety [14].

Parkinson's disease (PD) is a neurodegenerative disorder that can also affect the ability to drive. In a 2015 study involving 99 patients, a dichotomous decision pass/fail - was adopted using road assessment as the gold standard. The on-road assessment also identified possible additional assessments - positive with recommendations or irreparable. It thus highlighted the possibility of interventions aimed at improving their driving ability. Evaluating the tests - Making Trail Test B, Left Finger to Nose Test, and Contrast Sensitivity Measures were identified as significant predictors of subgroup transition. However, no significant predictors were identified for the subgroup, the negative result of which could be changed by actions improving cognitive functions [15].

This assessment was also made in a Spanish study on the possibility of people with PD to pass an exam in the law. The study included 37 patients and a control group of 33 people. Patients with an MMSE test result below 24 points, suggesting cognitive impairment, were excluded from the study. A number of neuropsychological tests were used - the point matching test, the block design test, driving performance tests, and daytime sleepiness tests. There were no significant differences in anticipation speed, multiple reaction time, attention span, and resistance to monotony. All participants successfully completed the daytime sleepiness tests. On the other hand, statistically significant differences were found between PD patients and the control group in terms of the speed of information processing; more patients with PD revealed a higher level of driving risk. In addition, PD patients had poorer visual-spatial abilities. The authors, taking into account the revealed differences, concluded that patients with PD should undergo a thorough neuropsychological assessment also in the early stages of the disease [16]. In the next study, participants - 19 people with PD and a control group of 21 - underwent a 45-minute road test in which they were assessed by a driving instructor and a second experimenter. To separate 'risky' drivers from 'safe' drivers, a compos- 
ite driving index was calculated based on the result of the driving test to assess their practical suitability for driving. Eight drivers, all diagnosed with PD, were assessed as "threatening". Both categories of drivers also distinguished the results of neuropsychological tests assessing cognitive functions in the group of drivers with PD [17].

Another clinical problem is the assessment of cognitive performance among people with a history of current or past abuse of psychoactive substances. Australian authors emphasize the need to meet the guidelines for remission of disorders and the lack of cognitive changes when considering applications for reissue of a driver's license. Assessing the fitness to drive for substance misuse and/or substance use disorders is a complex issue that requires the assessment of biomarkers, clinical outcomes, and clinical evaluation before returning to driving. The authors point to standardized psychological tests, which must be one of the elements of clinical evaluation [18].

Individual publications also concern other disorders of the mental sphere, in which an important element may be cognitive impairment. The study from 2019 presents the problem of the attention and behaviour function of a driver with a diagnosed attention deficit hyperactivity disorder (ADHD). In the study, apart from using a driving simulator, a computerized measurement of attention was carried out as a key symptom of the above dysfunction. In the entire study group of 87 people (16 people with ADHD, 71 healthy people), the speed of thinking was associated with the average and maximum throttle pressure and the maximum speed of travel. The findings confirmed previous studies showing the detrimental effect of increased impulsivity and attention disorders on driving safety [19]. A similar problem of mental disorders among young people, concerning autism and their ability to drive, was undertaken in 2018. A retrospective cohort study was conducted involving 52,172 New Jersey residents born between 1987 and 1995 who had been patients at The Hospital of Philadelphia health care network for at least 12 years; $609(1.2 \%)$ were diagnosed with ASD (Autism Spectrum Disorders). One in 3 adolescents with ASD obtained a driving license, compared with $83.5 \%$ for other adolescents, with the median being 9.2 months later. The vast majority $(89.7 \%)$ of people with ASD who obtained a permit and were fully eligible for a license acquired a license within 2 years [20].

\section{Cognitive dysfunctions and the ability to drive in selected somatic diseases}

Cognitive dysfunctions occurring in somatic diseases have been the subject of interest of many research groups in recent years. We would like to mention the most frequently identified and described ones, being aware that the catalogue of discussed problems could be much broader. These certainly include metabolic disorders, especially diabetes. According to various authors, the presence of diabetes symptoms may increase the risk of cognitive disorders and the dementia process by several times. This risk is increased by the early onset of diabetes symptoms, its duration, and the degree of disease control. The speed of cognitive processes, especially attention and executive functions, is most often impaired. Moreover, in type 2 diabetes, impairment of verbal and visual-spatial memory and thinking flexibility are observed [21].

According to the WHO, arterial hypertension ranks third among the causes of death in the general population. Elevated blood pressure is associated with the risk of cerebrovascular accidents, followed by cognitive impairment up to the development of dementia. Deterioration of cognitive functions is more intense among the elderly, although a decrease in cognitive performance was also observed among people up to 30 years of age. A higher value of systolic blood pressure is significantly associated with weaker scores on the Wechsler Intelligence Test of Wordless Scale. Clinical symptoms of cognitive dysfunction are related to the stage of disease severity. Memory impairment, executive function disorders, and attention disorders are observed, with the ability to function properly in everyday life. A similar deficit can also be observed in patients with ischaemic heart disease, and in this case disorders of the frontal functions - working memory - are also described [21].

An important but poorly understood issue is the assessment of cognitive functions both in the perioperative and postoperative periods in patients undergoing cardiac surgery. This study focuses on 2 aspects: deterioration of cognitive functions due to periprocedural impaired blood supply to the CNS and their potential improvement resulting from haemodynamic improvement after the procedure [22].

Cognitive functioning is also one of the essential elements in the course of the disease and treatment process in patients with respiratory dysfunction. In this case, the assessment of the efficiency of cognitive functions is also related to the degree of independence of the patient, including the ability to drive vehicles. Cognitive decline occurs in approximately $20 \%$ of patients with chronic obstructive pulmonary disease (COPD) and is believed to be associated with chronic hypoxia leading to brain dysfunction. Above all, hand-eye coordination, verbal fluency, memory processes, and concentration of attention are weakened. Similar deficits may occur in patients with asthma. It should also be added that many medications used in allergic diseases are excessively sedating, which may impair cognitive performance. Excessive daytime sleepiness also contributes to cognitive dysfunction in patients with obstructive sleep apnoea (OSA). Obstructive sleep apnoea affects everyday social func- 
tioning and increases the risk of accidents at work and road accidents. A particularly moderate or severe form of the disease may lead to impaired memory, attention, and thinking. Hence, in the current regulations on driver testing, a significant role is attached to the detection and appropriate treatment of drivers with OSA. Hypoxia during sleep causes sympathetic nervous system tension, which adversely affects the circulatory system. Therefore, these people are more likely to suffer from heart rhythm disturbances and hypertension than the control group, and they also have a higher risk of heart attack and stroke. The occurrence of these ailments while driving may have a direct impact on the increased risk of a road accident $[23,24]$.

Cerebral atrophy, leading to cognitive dysfunction, is a common problem among people suffering from chronic renal failure. Cognitive disorders in the disease worsen with the successive stages of renal failure. The risk of developing dementia is $2-7$ times higher in patients than in the general population. MMSE studies show that every fifth dialysis patient has mild cognitive impairment, and dementia is seen in $11 \%$. Cognitive disorders may exacerbate and sometimes mimic the symptoms of depression, also common in this group of patients [21].

Rheumatoid arthritis is a chronic, inflammatory, immune-mediated disease of connective tissue characterized by symmetrical arthritis and numerous extra-articular and systemic symptoms. One of the many complications of the disease are cognitive disorders caused by severe mood disorders, especially depressive ones, as well as symptoms of the disease, especially pain, and side effects of pharmacotherapy, especially chronic steroid therapy. The described decrease in cognitive performance in this group concerns verbal fluency, declarative memory, and eyehand coordination. Similar cognitive disorders in the course of systemic lupus erythematosus are also described in the literature [21].

It has also been shown that thyroid diseases, both hyperthyroidism and hypothyroidism, are associated with specific changes in the functioning of the central nervous system, which may result in disturbances in attention, reaction speed, memory, and information processing [25]. Previous studies show that even slight thyroid dysfunction is associated with changes in mood and cognitive dysfunction [26]. Cognitive impairment in hyperthyroidism in the course of Graves' disease may sometimes require psychiatric and psychological intervention. It seems that when examining candidates for drivers and drivers, in the case of diagnosing thyroid diseases, particular attention should be paid to the mental state of the respondents, because unbalanced hormonal disorders may significantly affect the ability to drive both in terms of cognitive functions and mood disorders [27].
In conclusion, it is also worth mentioning that, in addition to the diseases described above, the ability to drive in terms of cognitive performance can also potentially be affected by medications taken by drivers. Taking many medications prevents or limits the ability to drive by affecting the central nervous system, especially by slowing down the cognitive processes. Particular attention should be paid to hypnotics, anxiolytics, antidepressants, analgesics, and antihistamines. A physician authorized to examine drivers, in the event of a suspicion that the medicinal products used by the examined person may reduce the ability to drive, should order a full psychological or neuropsychological examination [24].

\section{Summary}

In the legal system in force in Poland, the assessment of the mental state of a person applying for a driving license or a driver is the responsibility of a doctor authorized to examine drivers. In many disease entities, one of the symptoms or complications may be disturbances of cognitive functions, affecting the ability to drive vehicles. This applies to both diseases that are primarily central nervous system dysfunctions and secondary complications of typically somatic disorders. The assessment of the efficiency of cognitive functions is undoubtedly an important element of a medical examination. As part of in-depth diagnostics, the neuropsychological examination in particular, on the basis of the analysed studies, has the greatest value in carrying out such an assessment and forecasting driving skills. It also seems that some psychological tests, due to their availability and simplicity, may be used for the initial assessment of cognitive disorders, e.g. the Mini Mental State Examination (MMSE) [28]. Any decision on the existence of contraindications to driving must be the result of in-depth diagnostics, and each time is individual, resulting from the course of the disease and identified dysfunctions. Cooperation between a doctor and a psychologist seems to be an indispensable element of the adjudication procedure.

\section{Conflict of interest}

The authors declare no conflict of interest.

\section{References}

1. Doliński D, Strelau J. Psychologia. Podręcznik akademicki. Gdańskie Wydawnictwo Psychologiczne, Gdańsk 2020.

2. Mosiołek A. Metody badań funkcji poznawczych. Psychiatria 2014; $11: 215-221$.

3. Piersma D, Fuermaier ABM, De Waard D, Davidse RJ, De Groot J, Doumen MJA, Bredewoud RA, Claesen R, Lemstra AF, Scheltens P, Vermeeren A, Ponds R, Verhey F, De Deyn PP, Brouwer WH, Tucha O. Assessing fitness to drive in patients with different types of dementia. Alzheimer Dis Assoc Disord 2018; 32: 70-75. 
4. Connors MH, Ames D, Woodward M, Brodaty H. Predictors of driving cessation in dementia: baseline characteristics and trajectories of disease progression. Alzheimer Dis Assoc Disord 2018; 32: 57-61.

5. Piersma D, Fuermaier AB, de Waard D, Davidse RJ, de Groot J, Doument MJA, Bredewoud RA, Claesen R, Lem stra AW, Vermeeren A, Ponds R, Verhey F, Brouwer WH, Tucha. Prediction of fitness to drive in patients with Alzheimer's dementia. Mult Scler 2018; 24: 1499-1506.

6. Connors MH, Ames D, Woodward M, Brodaty H. Mild cognitive impairment and driving cessation: a 3-year longitudinal study. Dement Geriatr Cogn Disord 2017; 44: 63-70.

7. Saviola D, De Tanti A, Conforti J, Posteraro R, Manfredini A, Bagattini C, Basagni B. Safe return to driving following severe acquired brain injury: role of a short neuropsychological assessment. Eur J Phys Rehabil Med 2018; 54: 717-723

8. McKay A, Liew C, Schönberger M, Ross P, Ponsford J. Predictors of the on-road driving assessment after traumatic brain injury: comparing cognitive tests, injury factors, and demographics. J Head Trauma Rehabil 2016; 31: 44-52.

9. Griffen JA, Rapport LJ, Bryer RC, Bieliauskas LA, Burt C. Awareness of deficits and on-road driving performance. Clin Neuropsychol 2011; 25: 1158-1178.

10. Marshall SC, Molnar F, Man-Son-Hing M, Blair R, Brosseau L, Finestone HM, Lamothe C, Korner-Bitensky N, Wilson KG. Predictors of driving ability following stroke: a systematic review. Top Stroke Rehabil 2007; 14: 98-114.

11. Selander H, Johansson K, Lundberg C, Falkmer T. The Nordic stroke driver screening assessment as predictor for the outcome of an on-road test. Scand J Occup Ther 2010; 17: 10-17.

12. Morrow SA, Classen S, Monahan M, Danter T, Taylor R, Krasniuk S, Rosehart R, He W. On-road assessment of fitness-to-drive in persons with MS with cognitive impairment: a prospective study. Mult Scler 2018; 24: 1499-1506.

13. Akinwuntan AE, Backus D, Grayson J, Devos H. Validation of a short cognitive battery to screen for fitness-todrive of people with multiple sclerosis. Can Fam Physician 2018; 25: 1250-1254.

14. Lincoln NB, Radford KA. Cognitive abilities as predictors of safety to drive in people with multiple sclerosis. Mult Scler 2008; 14: 123-128.

15. Classen S, Holmes JD, Alvarez L, Loew K, Mulvagh A, Rienas K, Walton V, He W. Clinical assessments as predictors of primary on-road outcomes in Parkinson's disease. OTJR 2015; 35: 213-220.

16. Badenes D, Garolera M, Casas L, Cejudo-Bolivar JC, Zaragoza S, Calzado N, Aguilar M. Relationship between neuropsychological tests and driver's license renewal tests in Parkinson's disease. Traffic Inj Prev 2018; 19: 125-132.

17. Ranchet M, Paire-Ficout L, Uc EY, Bonnard A, Sornette D, Broussolle E. Impact of specific executive functions on driving performance in people with Parkinson's disease. Mov Disord 2013; 28: 1941-1948.

18. Ogden EJD, Verster JC, Hayley AC, eDowney LA, Hocking B, Stough CK, Scholey AB, Bonomo Y. When should the driver with a history of substance misuse be allowed to return to the wheel? A review of the substance misuse section of the Australian national guidelines. Intern Med J 2018; 48: 908-915.
19. Bernstein J, Roye S, Calamia M, de Vito A. Utility of a novel simulator paradigm in the assessment of driving ability in individuals with and without attention-deficit hyperactivity disorder. Atten Defic Hyperact Disord 2019; 11: 403-411.

20. Curry AE, Yerys BE, Huang P, Metzger HB. Longitudinal study of driver licensing rates among adolescents and young adults with autism spectrum disorder. Autism 2018; 22: 479-488.

21. Talarowska M, Gałecki P. Zaburzenia funkcji poznawczych w wybranych chorobach somatycznych. Wydawnictwo Continuo, Wrocław 2013.

22. Proch M, Olasińska-Wiśniewska A, Łojko A, Grygier M. Ocena funkcji poznawczych u pacjentów poddanych zabiegowi przezcewkowego wszczepienia protezy zastawki aortalnej. Neuropsychiatr Neuropsychol 2016; 11: 135-142.

23. Siedlecka J, Rybacki M, Pływaczewski R, Czajkowska-Malinowska M, Radliński J, Kania A, Śliwiński P. Postępowanie lekarskie w obturacyjnym bezdechu sennym u osób kierujących pojazdami - zalecenia Polskiego Towarzystwa Medycyny Pracy, Polskiego Towarzystwa Chorób Płuc, Instytutu Medycyny Pracy w Łodzi i Polskiego Towarzystwa Badań nad Snem. Med Pr 2020; 71: 233-243.

24. Waszkowska M, Wężyk A. Badania psychologiczne w służbie medycyny pracy - regulacje prawne. Część I. Med Pr 2018; 69: 561-572.

25. Göbel A, Heldmann M, Göttlich M, Dirk AL, Brabant G, Munte TF. Effect of mild thyrotoxicosis on performance and brain activations in a working memory task. PLoS One 2016; 11: e0161552.

26. Bruscolini A, Sacchetti M, La Cava M, Nebbioso M, Iannitelli A, Quartini A, Lambiase A, Ralli M, Virgilio A, Greco A. Quality of life and neuropsychiatric disorders in patients with Graves' orbitopathy: current concepts. Autoimmun Rev 2018; 17: 639-643.

27. Morrison J. Diagnoza psychiatryczna. Wydawnictwo Uniwersytetu Jagiellońskiego, Kraków 2020.

28. Huisingh C, Wadley VG, McGwin Jr G, Owsley C. Relationship between areas of cognitive functioning on the Mini-Mental State Examination and crash risk. Geriatrics 2018; 3: 10.

\section{Address for correspondence:}

\section{Rafał Łoś}

Collegium Medicum

Jan Kochanowski University

Kielce, Poland

E-mail: rafal.los@ujk.edu.pl 